PRODUCTION

ENGINEERING ARCHIVES
2015, Vol. 8, No. 3, pp 14-17

ISSN 2353-5156 (print version)

ISSN 2353-7779 (online version)

\title{
Assessment of the functioning of quality mon- itoring system in steelwork based on the BOST method
}

\author{
Stanisław Borkowski ${ }^{1}$, Piotr Sygut ${ }^{2}$ \\ ${ }^{1}$ Institute of Production Engineering, Faculty of Management, Czestochova University of Technology, Armii Krajowej 19B, 42-201 \\ Czestochowa, Poland, e-mail: bork@zim.pcz.pl \\ ${ }^{2}$ Institute of Production Engineering, Faculty of Management, Czestochova University of Technology, Armii Krajowej 19B, 42-201 \\ Czestochowa, Poland, e-mail: piotr.sygut.wz@gmail.com
}

\begin{abstract}
This chapter presents the research results on the functioning of the quality control system at the steelworks. The study was conducted using an innovative BOST method. Highlighted the need to improve processes visual inspection as a means of improving the quality of finished products. Based on a survey conducted among employees of the production factors have been identified which require improvement process in question.
\end{abstract}

Key words - BOST method, correlation analysis, the characteristics of workers, statistical analysis, the series of validity

\section{Introduction}

Variability and dynamics of the contemporary world economy forces entrepreneurs to continually improve product quality at every stage of production. Economic policy based company to improve existing processes should be one of the stages of raising the production quality. The key criterion influencing the success is skillful predicting of the area and determining factors for improvement, and then identifying the weakest of them. Priority setting processes in taking action are observed and identifying problem areas and quickly and easily improving the competitiveness of modern enterprises.

This chapter attempts to identify the factors that require improvements in order to improve the quality of visual control in the company. An analysis was made of these factors on the basis of assessments of respondents considering their individual personal characteristics. The data obtained made it possible to systematize the factors considered the ranks of validity. So the operations conducted made it possible to develop lines of business activities in order to minimize or eliminate difficulties in the designated quality control.

The basic steelwork product groups surveyed are long products (sections, rails and railway accessories, all kinds of tubes, rods and the wires in the mats construction with rebar), mining and steel housing flat products, which consists of sheet metal and various kinds of tape. 


\section{The structure of the respondents characteristics}

Table 1 presents the percentage characteristic traits. In the survey of 30 respondents was attended. The structure of the characteristics of the respondents were analyzed in accordance with the procedure set forth in the works (BORKOWSKI S. 2014; INGALDI M. 2014, SzKLaRZYK P., Klimecka-Tatar D., Sygut P., LIPIŃSKI T. 2014). Among the respondents were men $-60 \%$, and $40 \%$ women. Most respondents had secondary education - $47 \%$ of those surveyed, $27 \%$ lower than the average, $20 \%$ higher degree and $7 \%$ higher secondary level.

Table 1. Features of respondents. A percentage characteristics

\begin{tabular}{|c|c|c|c|c|c|c|}
\hline \multirow{2}{*}{ Symbol } & \multicolumn{6}{|c|}{ Designation features and a percentage their characteristics } \\
\hline & MK & WE & wi & sc & MR & TR \\
\hline 1 & 60 & 27 & 20 & 10 & 7 & 40 \\
\hline 2 & 40 & 47 & 23 & 17 & 30 & 23 \\
\hline 3 & & 20 & 17 & 27 & 17 & 37 \\
\hline 4 & & 7 & 7 & 7 & 17 & \\
\hline 5 & & & 13 & 3 & 20 & \\
\hline 6 & & & 10 & 17 & 10 & \\
\hline 7 & & & 10 & 10 & & \\
\hline 8 & 30 & & & 10 & & \\
\hline
\end{tabular}

Source: own

Percentage distribution in relation to age is as follows: under 30 years old is $20 \%$ of the respondents, aged $31-40$ years is housed $23 \%, 17 \%$ is the share of workers between $41-50$ years old, $7 \%$ between the ages of 51- 55 years, $13 \%$ are over 56 years old but does not exceed 60, and the oldest group representing $20 \%$ of all respondents, with $10 \%$ of housed in the ages between 61-65 years of age and 10\% over the next 66 years. On the other hand, taking into account the differences between respondents according to their seniority, it can be said that most employees have much experience, as many as $90 \%$ of employees working more than 6 years, of which $27 \%$ is in the range 11-15 years of work, $37 \%$ has overworked at least 26 years, and only 3 people (representing $10 \%$ of the respondents) work for less than 5 years. Analyzing the mobility of workers - determining which, in turn, the workplace is present company - that, as many as $30 \%$ of respondents declared the second place of employment and only $7 \%$ of respondents claim that this is their first job. For $17 \%$, the company is the third place of work and the same people who took a job for the fourth time. $20 \%$ of respondents are already working on the fifth plant and $10 \%$ in the sixth.

The last feature of the respondents under consideration in the survey was arrangements for admission to work. Of all respondents $40 \%$ were admitted to work in normal mode for a $23 \%$ position held it was the result of a transfer from another, while $37 \%$ took up a job due to better financial conditions.

In Figure 1 shows a graphical interpretation of the structure characteristics of respondents on which numerical values are shown for the six above-mentioned issue and personal characteristics of respondents.

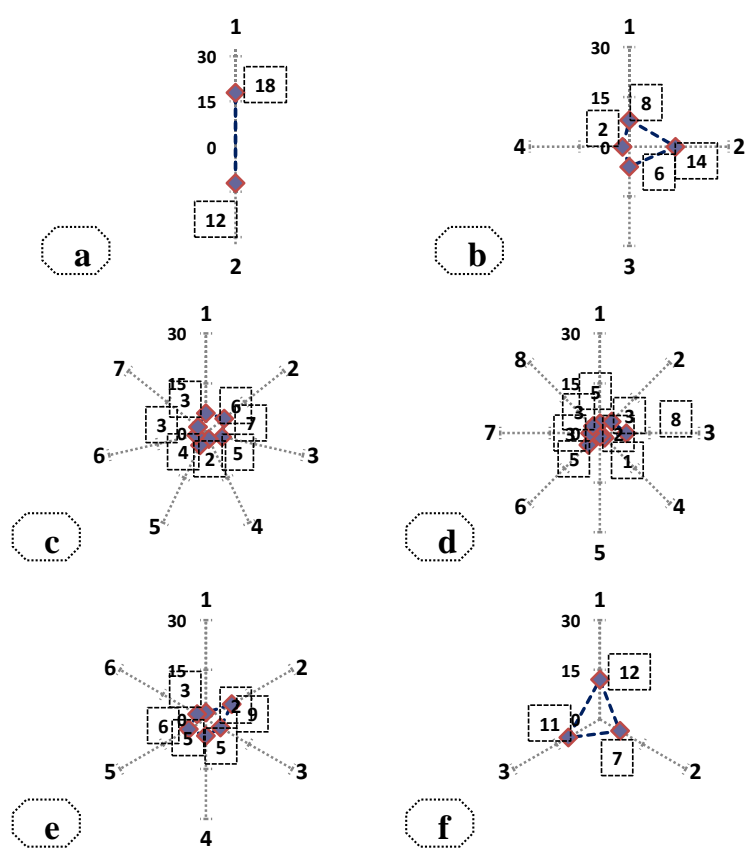

Fig. 1. Radar charts. Characteristics (numerical) of the respondents taking into account: a) sex, b) education, c) age d) seniority, e) the mobility f) arrangements for admission to work

Source: own

\section{Results presentation of the BOST survey}

BOST results of the study are based on surveys conducted among employees of the analyzed company. 
The analysis was based on the work (BORKOWSKI S., 2014). It was found the most important factors that influence the quality of visual inspections carried out. Respondents were asked to answer the question: What is the most important element in visual inspection? and assigning a set of factors of 1 to 6 , where assessment "6" meant the most important factor and "1" in the least significant in visual inspection. Are the following factors:

- cleanliness, order (CS),

- flow (EP),

- information boards (TI),

- participation in production (UP),

- monitoring (ME),

- graphical presentation of results (GW).

These factors describing the principle of 7 management of Toyota in the personal content of the survey are so-called E7 area. The percentage statement obtained grades importance of individual factors is presented in Table 2.

Table 2. Principle 7 percentage a statement of evaluations validity factors $\mathrm{E} 7$ area

\begin{tabular}{|c|c|c|c|c|c|c|}
\hline \multirow{2}{*}{ Evaluation } & \multicolumn{6}{|c|}{ Determination of factors } \\
\cline { 2 - 7 } & CS & EP & TI & UP & ME & GW \\
\hline 1 & 0,0 & 16,7 & 30,0 & 16,7 & 13,3 & 23,3 \\
\hline 2 & 23,3 & 13,3 & 16,7 & 13,3 & 20,0 & 13,3 \\
\hline 3 & 23,3 & 13,3 & 20,0 & 13,3 & 13,3 & 16,7 \\
\hline 4 & 23,3 & 6,7 & 16,7 & 23,3 & 13,3 & 16,7 \\
\hline 5 & 16,7 & 13,3 & 13,3 & 16,7 & 30,0 & 10,0 \\
\hline 6 & 13,3 & 36,7 & 3,3 & 16,7 & 10,0 & 20,0 \\
\hline
\end{tabular}

Source: own

Based on the analysis determined the process that according to respondents is the most important factor in the visual examination in the study area - it is the flow (EP). This area received the highest number of points assigned to assess "6" as much as $36.7 \%$ and the sum of ranks "5" and "6" for this factor represents 50\% of grades. Second most important factor is monitoring (ME) represents $40 \%$ of the votes in the evaluation "5" and "6". Such a statement reveals that it is these two factors are most important during the visual inspection in the processes occurring in the production of steel companies. Analyzing the data in Table 2 draws attention to the fact that factor information boards (TI) received the highest evaluations of "1" acting $30 \%$ of the votes of respondents. Areas evaluated "2", "3" and "4" are comparatively scored, which means that the validity of these factors is at a similar level. The presented methodology used in the analysis also in publications (SYGUT P., BORKOWSKI S., KLIMECKA-TATAR D., SZKLARZYK P., 2014, BORKOWSKI S., SYGUT P., 2014).

\section{Construction of the validity ranks}

In order to obtain the structure of the factors used in the graphical analysis of Pareto-Lorenz (Fig. 11.2). Presented distribution of scores shows the importance of various factors in order of decreasing relative contribution of each factor controls the total effect. The result of such an analysis is to determine which of the designated areas must first undergo process improvement, minimize errors, or if possible remove in order to get the best performance improvement and quality control processes.
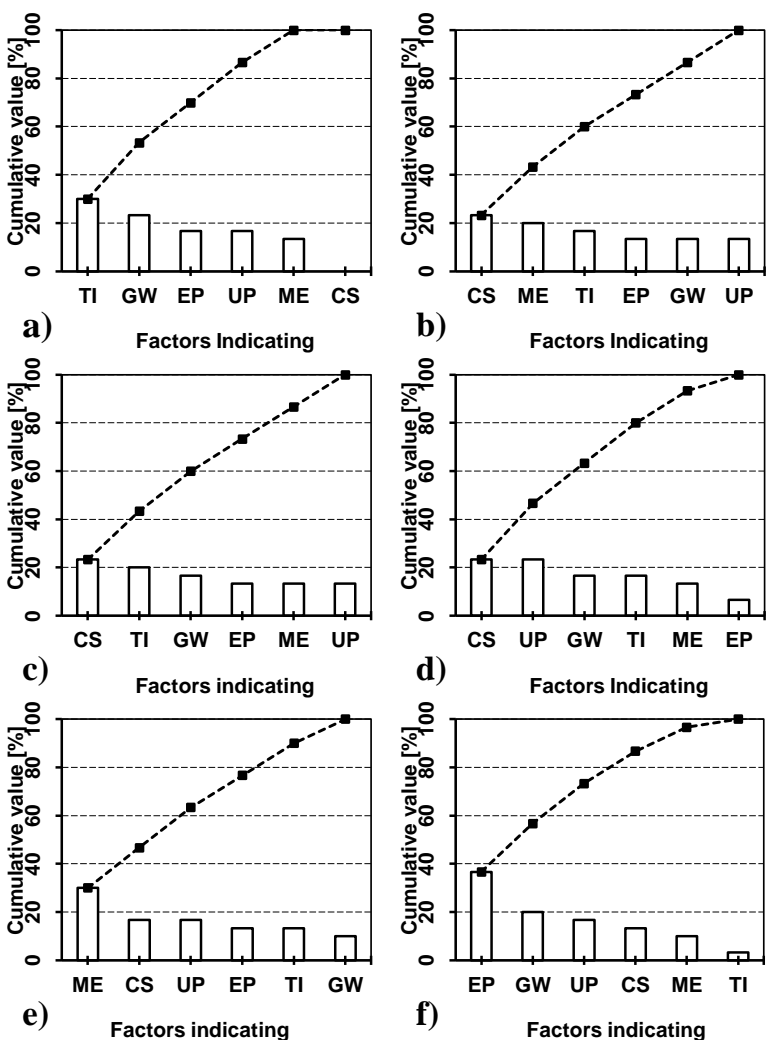

b)

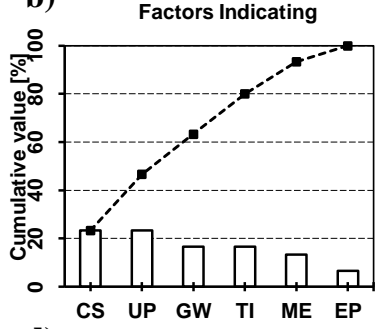

d)

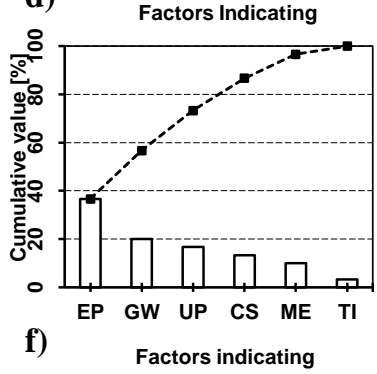

Fig. 2. Principle 7 Pareto-Lorenz of the factors $E 7$ area for evaluations: a) ,1”, b) ,2”, c),3”, d) ,4, e) ,5”, f) ,6”

Source: own 
Based on the analysis of Pareto-Lorenz (Fig. 2), shows the ranks of the factors for the different factors describing the principle of management Toyota 7 E7 for ratings $1-6$ :

- evaluation: ,1": TI $>\mathrm{GW}>(\mathrm{EP} ; \mathrm{UP})>\mathrm{ME}>\mathrm{CS}$

- evaluation: „2": CS>ME>TI $>$ (EP; GW; UP)

- evaluation: ,3”: $\mathrm{CS}>\mathrm{TI}>\mathrm{GW}>(\mathrm{EP} ; \mathrm{ME}$; UP)

- evaluation: „4": (CS; UP $)>(\mathrm{GW} ; \mathrm{TI})>\mathrm{ME}>\mathrm{EP}$

- evaluation: ,5": ME $>(\mathrm{CS} ; \mathrm{UP})>(\mathrm{EP} ; \mathrm{TI})>\mathrm{GW}$

- evaluation: „6": $\mathrm{EP}>\mathrm{GW}>\mathrm{UP}>\mathrm{CS}>\mathrm{ME}>\mathrm{TI}$

\section{Conclusion}

The paper presents the role that the selected factors play in the visual inspection process. The results of the analysis were based on the principle 7 Toyota's management according to the BOST method. This principle has been described six factors for which specific numerical estimate of average importance. The results are shown in Figure 3.

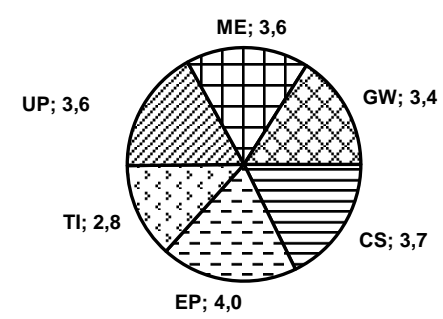
Fig. 3. Average (numerical) evaluation of the factors E7
area

Source: own

A series of validity for the data in Figure 11.4, taking into account the factors set out in the analyzed company is as follows:

$$
\mathrm{EP}>\mathrm{CS}>(\mathrm{UP} ; \mathrm{ME})>\mathrm{GW}>\mathrm{TI}
$$

This rating confirms that the opinion of respondents flow factor (EP) is the most important in the hierarchy of importance of individual factors, and information boards factor (TI) occupying last place in the series and thus becomes the least important in a visual inspection.

BOST method allows the study to assess the validity of factors that play an important role in the visual inspection process. Objective analysis has been achieved, since results obtained allowed the determination of the structure of the validity of the individual elements E7 area, the characteristics of respondents and the relationship between the factors abovementioned area and characteristics of respondents.

\section{References}

1. BORKOWSKI S. 2014a. Znaczenie kontroli wizualnej podczas produkcji środków transportowych. Rozdziat 4.[W:]BorkOWsKi S., InGALDI M. (red). Toyotaryzm, Zagadnienie kontroli w metodzie BOST. Oficyna Wydawnicza Stowarzyszenia Menadżerów Jakości i Produkcji. Częstochowa, s.49-58.

2. BORKOWSKI S. 2014b. Struktura kontroli jakości podczas produkcji materiatów budowlanych. Rozdziat 5.[W:]BORKOWSKI S., INGALDI M. (red). Toyotaryzm, Zagadnienie kontroli w metodzie BOST. Oficyna Wydawnicza Stowarzyszenia Menadżerów Jakości i Produkcji. Częstochowa, s. 61-71.

3. INGALDI M. 2014. Miejsce kontroli wizualnej w przedsiębiorstwie branży metalowej. Rozdziat 6. [w:] BORKOWSKI S., INGALDI M. (red). Toyotaryzm, Zagadnienie kontroli w metodzie BOST. Oficyna Wydawnicza Stowarzyszenia Menadżerów Jakości i Produkcji. Częstochowa, s.74-85.

4. SZKLARZYK P., KLIMECKA-TATAR D., SYGUT P., LIPIŃSKI T. 2014, Quality Assessment of the Hot-Rolled Products. (w:) Identification of the Factors Demanding for Improvement in the Engineering Material Production. Scientific Monography. Scientific Editors: Stanisław Borkowski, Tomasz Lipiński, Celje: Faculty of Logistics, University of Maribor, s. 41-52, ISBN 978-9616562-96-6.

5. SyGUT P., Borkowski S., KLIMECKa-TataR D., SZKLARZYK P., 2014, The Importance of Visual Inspection in Flat Products Rolling Process. (w:) Identification of the Factors Demanding for Improvement in the Engineering Material Production. Scientific Monography. Scientific Editors: Stanisław Borkowski, Tomasz Lipiński. Celje: Faculty of Logistics, University of Maribor, s. 53-64, ISBN 978-961-6562-96-6.

6. BORKOWSKI S., SYGUT P., 2014, The Quality of Iron Alloy Products. Monography. Scientific Editors Stanisław Borkowski, Piotr Sygut. Częstochowa: Oficyna Wydawnicza Stowarzyszenia Menedżerów Jakości i Produkcji, ISBN 978-83-63978-14-3. 